\title{
Auditor Tenure and Accounting Conservatism: Testing Moderating Effect of Owner's Importance
}

\author{
Mehrdad Dadgar Arabloo \\ Department of Management and Accounting \\ Central Tehran Branch, Islamic Azad University \\ Tehran, Iran
}

\begin{abstract}
Conservatism is one of the salient features of financial reporting that has attracted more attention in recent years because of financial scandals. Several recent studies have focused specifically on conservatism. This research tries to investigate the effect of auditor tenure and the importance of the client's accounting conservatism by using panel data model, multivariate regression, and data of 114 companies listed in Tehran Stock Exchange during the years 2011 to 2015. The results showed that there is an inverse relationship between auditor tenure and conservatism of auditees; moreover, the client's importance has an additive effect on the inverse relationship between auditor tenure and conservatism of client.
\end{abstract}

Keywords-auditor tenure; accounting conservatism; importance; client

\section{INTRODUCTION}

Observing the principle of conservatism is a component of reliability of the information. In [1], it was stated that conservatism is a different verifiability to identify revenues and costs that leads to understatement of profits and assets. Conditional conservatism, which will be considered in this study, is also called post-event conservatism or conservatism affiliated with News. It signifies timely recognition of bad news from good news in the event of profit (loss). Therefore, conservative policies by providing a negative picture of the financial situation and profitability of the business unit reduces pressures and the threat of competition on the one hand and moderates shareholders and investors' expectations of future performance of the business unit on the other hand. By assessing the benefits and costs of adopting a conservative or aggressive approach, managers do seek to maximize wealth of their stakeholders. It seems that conservatism increases with increasing competitive pressures. Conservatism is one of the salient features of financial reporting that has attracted more attention in recent years because of financial scandals. Although many accountants agree on the presence of conservatism in the regulation of the financial statements, no comprehensive definition has been provided for conservatism. However, two major features of conservatism been examined in accounting texts. First, downward siding of the book value of capital relative to market value; second, tendency to accelerate the identification of costs and delay in the recognition of revenue. It is stated in paragraph 95 of
Statement of Financial Accounting Concepts No. 2, "If two amounts are not equally likely, conservatism does not necessarily dictate using the more pessimistic amount rather than the more likely one". From the perspective of financial statement preparers, conservatism is as an attempt to choose a method of accepted accounting methods that result in one of the following items: slower revenue recognition, rapid diagnosis cost, lower valuation of assets, or higher evaluation of debts. In Statement of Financial Accounting Concepts No. 2, Financial Accounting Standards Board has reduced to some extent from the importance of conservatism because there is no sign of it in the hierarchy of features. The statement does not confirm presentation of undercounting value of the assets or profits (or offering more value than actually). However, researchers have presented some explanations for conservative financial reporting. All explanations show that conservatism is useful to users of accounting reports. The explanations include (1) contractual explanation, (2) legal proceedings explanation, (3) income tax explanation, and (4) legal explanation [2].

Experts, researchers, and official bodies setting accounting and auditing standards as well as professional conduct rituals try to classify factors that can affect the quality of audit. Most of them have adopted a normative view and they emphasize on factors such as independence, professional competence, professional skepticism, planning and proper supervision of audit work and so on. Some other experts adopted a descriptive approach and they have considered auditor reputation, his membership in professional associations and organizations, auditor size, auditor expertise in a particular industry [3], audit fees [4], and results of coworkers [5] as factors affecting audit quality. This research emphasizes on the issue of auditor tenure and the relative importance of the client. The results of previous empirical studies [6] indicate the relationship between auditor tenure and audit quality. The company management has the primary responsibility for preparing the financial statements; but the accusing finger has pointed towards auditors in recent financial scandals in the world so that these events are generally called "failure of auditing". It is believed generally that lack of independence and poor quality of the audit has led to such incidents. Following these events, regulators and accounting standard developers have tried to formulate regulations for improving auditor independence and audit quality [7]. For example, ratification of Sarbanes-Oxley 
Act of 2002 is an effort in this regard. Section 203 of the Act obliges the audit firms that change their associates and managers after 5 consecutive years of working on a client [8]. In addition, as stated in [9], auditors show more leniencies to the clients who are more important in terms of remuneration and credit. Accordingly, they try more to maintain the client. With these lines, this study investigates the effect of auditor tenure and the importance of the client on the auditees' conservatism in the companies listed in Tehran stock exchange.

\section{RESEARCH BACKGROUND AND LITERATURE REVIEW}

According to [3], conservatism means that the accountant must report the lowest value for assets and highest value for its liabilities among the possible values. Revenue should be recognized later, not sooner; costs should be recognized sooner rather than later. Accounting conservatism can be defined as the tendency of accounting in application of higher degree of verifiability for recognition of good news versus bad news [2]. Conservatism is a different verifiability to identify revenues and costs that leads to understatement of profits and assets. Recent studies have divided conservatism into conditional and unconditional conservatism [1]. Numerous studies suggest adopting a conservative approach in normal conditions because interests of conservative approach outweigh its costs [1]. The effects of conservatism can be attributed to two issues. First, financial reporting standards that obligates conservative reporting; second, accounting practices selected by management to prepare financial statements. The second aspect is usually regarded as the image of conservatism in related literature. For example, conservative financial reporting by a company could imply the existence of higher uncertainty, higher risk, and eventually more conservatism; hence, it is obligated in the related standards. It may also indicate that the company has selected conservative accounting procedures for financial reporting. In the real world, both of them may be important and their relative importance differs. Thus, companies aiming to provide conservative financial reports may not represent significant level of conservatism if the level of uncertainty and ambiguity is low. On the contrary, company with an aggressive policy of financial reporting may represent a significant level of conservatism if the level of uncertainty and ambiguity is high [10]. Moreover, according to [11], long-term relationship between the auditor and the auditee creates a friendship between them; thus, it may reduce the reliability of financial statements. In 1996, the Government Accounting Office in the United States announced that major frauds in the country had caused by most long-term relationships between auditor and auditee. It is not clear whether the mandatory auditor rotation is real solution to the problems related to poor quality of financial reporting. Previous studies have shown that in the early years of interaction with the client auditor's motives may be different from other years. In general, auditor incentives relates to the balance between the tendency of auditors to maintain and benefit from the relationship between the auditor and the auditee [12]. Auditing quality is a function of education, training, and knowledge of professional standards with the independence and impartiality, auditors' awareness of the client's industry and business operations, and the relationship between active auditing team and management of the client's company. There are two schools of thought about long-term audit tenure of auditory institutions. The first school of thought believes that auditory institutions with long-term audit tenure have relatively more knowledge of industry and business of a company and they can present higher quality and more auditing performance [11, 13-15]. Another school of thought claims that in auditory institutions with long-term audit tenure, there is the possibility of familiarity (or even friendship) between the audit team members and client's staff that increases the probability of destruction of auditing program. It reduces the likelihood of making decisions contrary to past years; hence, they may present and less efficient and lower quality auditing [16-20]. This school of thought has attracted the attention of many countries. In this regard, the results of [21] show that percent increase in the auditing quality of small companies is higher than large companies. In other words, audit quality improves when the audited units are smaller. In [22], authors concluded that changing audit institutions is generally useful the costs associated with changing audit institutions is less than its advantages. In [23], it was concluded that Egyptian auditors are fully aware of the concept of audit quality and they agree with benefits of long-term relationship with the client in order to increase audit quality. The results of his study showed that mandatory rotation of audit institutions is a good strategy to increase independence of auditing institutions in Egypt. In [24], authors concluded that increasing audit tenure leads to increasing audit quality. The results of [9] showed that the amount of clients' accounting conservatism reduce with increasing auditor tenure. However, the relative importance of client in relation to auditor tenure and accounting conservatism has been evaluated insignificant. In Iran, the findings in [25] represent that auditor rotation is directly related to the change in auditor's opinion. The results of [26] indicate the direct and significant relationship between changing audit institutions and conservative earnings reporting of companies listed on the Tehran Stock Exchange. Overall, findings suggest that changing audit institution increases conservatism in profits reported by companies listed on the Tehran Stock Exchange [27] concluded that there is a significant relationship between independent auditor rotation and audit report. In terms of auditor rotation type, the result of hypothesis testing indicates that there is no significant relationship between auditor rotation type and audit report in the surveyed firms.

\section{RESEARCH HYPOTHESES}

According to the explanations provided in theoretical foundations and literature review, hypotheses are put forward as follows:

- There is an inverse relationship between auditor tenure and accounting conservatism of clients.

- Client importance has additive effect on the inverse relationship between auditor tenure and conservatism of clients. 


\section{RESEARCH METHODOLOGY}

Since results of this study can be used in decisions of managers, investors, analysts, capital market participants, the Securities and Exchange, and auditors, this is a practical research in terms of objectives. Besides, this is a descriptivecorrelational research with respect to the way to deduce the hypotheses because it employs regression and correlation techniques to uncover the relationships among variables. Accordingly, it uses inductive reasoning for its purposes. In addition, this is a positive research because the researcher makes their conclusion based on testing the available data.

\section{RESEARCH MODELS AND VARIABLES}

The following models are used to test the research hypotheses:

Net Income ${ }_{i, t}=\alpha_{0}+\alpha_{1}$ Stock Return $_{i, t}+$

$\alpha_{2}$ Dummy Negative Stock Return $_{\mathrm{i}, \mathrm{t}}+$

$\alpha_{3}$ Stock Return $_{\mathrm{i}, \mathrm{t}} *$ Dummy Negative Stock Return $_{\mathrm{i}, \mathrm{t}}+$

$\alpha_{4}$ Auditor Tenure $_{i, \mathrm{t}}+\alpha_{5}$ Auditor Tenure $_{\mathrm{i}, \mathrm{t}}{ }^{*}$ Stock Return ${ }_{\mathrm{i}, \mathrm{t}}$

$+\alpha_{6}$ Auditor Tenure $_{i, t} *$ Dummy Negative Stock Return ${ }_{i, t}+$

$\alpha_{7}$ Auditor Tenure ${ }_{i, t} *$ Dummy Negative Stock Return $_{\mathrm{i}, \mathrm{i}}$ *Stock Return St, $_{\mathrm{i}, \mathrm{t}}$

$+\alpha_{8}$ Client Importance $_{\mathrm{i}, \mathrm{t}}+\alpha_{9}$ Client Importance $_{\mathrm{i}, \mathrm{t}}{ }^{*}$ Stock Return $_{\mathrm{i}, \mathrm{t}}+$

$\alpha_{10}$ Client Importance $e_{i, t} *$ Dummy Negative Stock Return ${ }_{i, t}+$

$\alpha_{11}$ Client Importance $_{\mathrm{i}, \mathrm{t}} *$ Stock Return $_{\mathrm{i}, \mathrm{t}} *$

Dummy Negative Stock Return ${ }_{i, t}+$

$\alpha_{12}$ ClientImportance $_{i, t} *$ Auditor Tenure $_{i, t} *$ Stock Return $_{\mathrm{i}, \mathrm{t}}$

* Dummy Negative Stock Return ${ }_{i, t}$

$+\alpha_{13}$ Firm Size $_{i, \mathrm{t}}+\alpha_{14}$ Leverage $_{\mathrm{i}, \mathrm{t}}+\varepsilon_{\mathrm{i}, \mathrm{t}}$

Where

1) Dependent variable:

- Net Income $_{i, t}$ : Net income of company $i$ in year $t$, which is the ratio of net income to total assets.

2) Independent variables:

- Stock Return ${ }_{\mathrm{i}, \mathrm{t}}$ : Stock returns of the company that is equal to the sum of dividend per share and difference of the share market prices at the end of the year and the beginning of the year divided by Share market price at the beginning of the year;

- Dummy Negative Stock Return $n_{i, t}$ : Negative stock returns that is marked by one if it is negative; otherwise it is marked by zero;

- Auditor Tenure i,t $_{\mathrm{t}}$ : Company auditor tenure that is equal to the number of continuous cooperation between audit firm and client.

- Client Importance $e_{i, t}$ : The importance of client of audit firm. It is marked by one if proportion of sales revenue for the client to sales revenue for all clients of the audit firm is greater than 0.2 ; otherwise, it is marked by zero.

3) Control variables:

- $\quad$ Firm Size $_{\mathrm{i}, \mathrm{t}}=$ Company size, which is equal to natural logarithm of total assets.

- Leverage $_{\mathrm{i}, \mathrm{t}}=$ Financial leverage is the ratio of total debt to total company assets.

\section{STATISTICAL POPULATION AND STATISTICAL SAMPLE}

Research statistical population includes companies listed on Tehran Stock Exchange during the years 2011 to 2015. The sample will be selected through a systematic elimination from the statistical population. In this manner, sample contains all available companies in the population with the following criteria:

- It should have no change in financial period during the intended period.

- It should be regarded as active companies in the area of financial activities and it should not be from investment companies, banks, insurance companies, and financial institutions.

- Data for the variables should be available during the period 2011 to 2015.

- Their financial year ended in 21 March (last day of Persian calendar) to enable researcher to used panel data in $=\mathrm{f}$ it is necessary.

The process leads to selection of 114 companies.

\section{RESEARCH FINDINGS}

\section{A. Descriptive Statistics}

The required descriptive indicators of variables including mean, median (central criteria), standard deviation, maximum, and minimum (scattering parameters) have been calculated. The results are represented in Table I.

TABLE I. DESCRIPTIVE INDICATORS OF THE STUDIED VARIABLES

\begin{tabular}{|c|c|c|c|c|c|}
\hline $\begin{array}{c}\text { Research } \\
\text { variables }\end{array}$ & Mean & Median & Maximum & Minimum & $\begin{array}{c}\text { Standard } \\
\text { deviation }\end{array}$ \\
\hline Net Income & 0.112 & 0.09 & 0.631 & -0.289 & 0.125 \\
\hline Stock returns & 0.329 & 0.037 & 4.7 & -0.783 & 0.937 \\
\hline $\begin{array}{c}\text { Negative } \\
\text { stock returns }\end{array}$ & 0.456 & 0.000 & 1.000 & 0.000 & 0.498 \\
\hline $\begin{array}{c}\text { Auditor } \\
\text { tenure }\end{array}$ & 4.026 & 3.000 & 15.000 & 1.000 & 3.936 \\
\hline $\begin{array}{c}\text { importance } \\
\text { of audit firm } \\
\text { client }\end{array}$ & 0.207 & 0.000 & 1.000 & 0.000 & 0.405 \\
\hline $\begin{array}{c}\text { Company } \\
\text { size }\end{array}$ & 13.835 & 13.741 & 19.106 & 10.166 & 1.441 \\
\hline $\begin{array}{c}\text { Financial } \\
\text { leverage }\end{array}$ & 0.579 & 0.584 & 0.986 & 0.065 & 0.188 \\
\hline
\end{tabular}

Mean is considered as the main and most important central index. Mean indicates equilibrium and center of distribution; median is the point dividing a sample into two equal parts. As it can be seen in the above table, the mean value of the variable stock returns is 0.329 and its median is 0.037. In general, distribution measures evaluate the dispersion of samples around the mean. Standard deviation is one of the most important distribution measures. According to the table above, this measure for the variable stock returns is equal to 4.7 and its minimum is -0.783 . Characteristics of all variables are evident in the Table I. 


\section{B. Inferential Statistics}

Results of testing the research hypotheses through fixed effects model and generalized least squares estimation method are mentioned in Table II.

TABLE II. RESULTS OF TESTING HYPOTHESES

\begin{tabular}{|c|c|c|c|c|}
\hline Variables & Coefficients & $\begin{array}{l}\text { Standard } \\
\text { deviation }\end{array}$ & $\begin{array}{c}\text { T- } \\
\text { statistics }\end{array}$ & $\begin{array}{c}\text { Significance } \\
\text { level }\end{array}$ \\
\hline Fixed value & 0.526 & 0.042 & 12.332 & 0.000 \\
\hline Stock returns & 0.015 & 0.002 & 7.751 & 0.000 \\
\hline $\begin{array}{l}\text { Negative stock } \\
\text { returns }\end{array}$ & 0.002 & 0.005 & 0.481 & 0.63 \\
\hline $\begin{array}{c}\text { Negative stock } \\
\text { returns* Stock } \\
\text { returns } \\
\end{array}$ & -0.096 & 0.019 & -5.003 & 0.000 \\
\hline Auditor tenure & -0.0008 & 0.0006 & -1.267 & 0.205 \\
\hline $\begin{array}{c}\text { Stock returns } \\
* \text { Auditor tenure }\end{array}$ & 0.01 & 0.006 & 1.783 & 0.075 \\
\hline $\begin{array}{c}\text { Auditor tenure* } \\
\text { Negative stock } \\
\text { returns }\end{array}$ & 0.0009 & 0.001 & 0.58 & 0.561 \\
\hline $\begin{array}{c}\text { Auditor tenure* } \\
\text { Stock returns* } \\
\text { Negative stock } \\
\text { returns }\end{array}$ & 0.036 & 0.004 & 8.332 & 0.000 \\
\hline $\begin{array}{c}\text { Client } \\
\text { importance }\end{array}$ & 0.025 & 0.009 & 2.708 & 0.007 \\
\hline \begin{tabular}{l}
\multicolumn{1}{c}{ Client } \\
importance* \\
Stock returns \\
\end{tabular} & 0.002 & 0.005 & 0.471 & 0.637 \\
\hline $\begin{array}{c}\text { Client } \\
\text { importance* } \\
\text { Negative stock } \\
\text { returns }\end{array}$ & -0.006 & 0.016 & -0.384 & 0.701 \\
\hline $\begin{array}{c}\text { Client } \\
\text { importance* } \\
\text { Stock returns* } \\
\text { Negative stock } \\
\text { returns } \\
\end{array}$ & 0.037 & 0.35 & 1.025 & 0.305 \\
\hline $\begin{array}{c}\text { Client } \\
\text { importance } * \\
\text { Auditor tenure* } \\
\text { Stock returns* } \\
\text { Negative stock } \\
\text { returns } \\
\end{array}$ & 0.015 & 0.005 & 3.117 & 0.002 \\
\hline Company size & -0.015 & 0.003 & -4.865 & 0.000 \\
\hline $\begin{array}{l}\text { Financial } \\
\text { Leverage }\end{array}$ & -0.351 & 0.025 & -14.048 & 0.000 \\
\hline F-statistic & 64.803 & \multicolumn{2}{|c|}{$\begin{array}{c}\text { Adjusted coefficient of } \\
\text { determination }\end{array}$} & 0.537 \\
\hline $\begin{array}{c}\text { Significance level } \\
\text { of F-statistics }\end{array}$ & 0.000 & \multicolumn{2}{|c|}{$\begin{array}{c}\text { Durbin-Watson } \\
\text { Coefficient }\end{array}$} & 2.019 \\
\hline $\begin{array}{c}\text { significance level } \\
\text { Chow Test }\end{array}$ & 0.000 & \multicolumn{2}{|c|}{$\begin{array}{c}\text { Hausman test } \\
\text { significance level }\end{array}$} & 0.004 \\
\hline
\end{tabular}

According to the results of Table II, since t-statistic for the variable Negative stock returns* Stock returns is greater than 1.965 and its significance level is less than 0.05 , there is significant inverse relationship between Negative stock returns* Stock returns and net income of listed companies in Tehran Stock Exchange. Therefore, existence of conservatism is confirmed in the studied sample. Moreover, since t-statistic for the variable Auditor tenure* Stock returns* Negative stock returns is greater than +1.965 and its significance level is less than 0.05 , there is a significant direct relationship between
Auditor tenure* Stock returns* Negative stock returns and net income of listed companies in Tehran Stock Exchange. Accordingly, increasing auditor tenure reduces company-wide accounting conservatism. In this way, the first hypothesis of this study is confirmed. In addition, since t-statistic for the variable Client importance*Auditor tenure* Stock returns *Negative stock returns is greater than +1.965 and its significance level is less than 0.05 , there is a significant direct relationship between Client importance*Auditor tenure* Stock returns* Negative stock returns and net income of listed companies in Tehran Stock Exchange. Thus, increasing client's importance strengthens destructive effect of auditor tenure on accounting conservatism in a company.

\section{CONCLUSION}

According to available theoretical and empirical evidence, conservative financial reporting by a company could imply the existence of higher uncertainty, higher risk, and eventually more conservatism; hence, it is obligated in the related standards. It may also indicate that the company has selected conservative accounting procedures for financial reporting. In the real world, both of them may be important and their relative importance differs. With emphasis on the concept of accounting conservatism, this study has tried to investigate the effect of auditor tenure on accounting conservatism companies using data from 114 companies listed on Tehran Stock Exchange during the five-year period ending in 2015. The results of testing the first hypothesis of research indicated that increasing auditor tenure reduces accounting conservatism. It should be noted in this regard that conservative policies by providing a negative picture of the financial situation and profitability of the business unit reduces pressures and the threat of competition on the one hand and moderates shareholders and investors' expectations of future performance of the business unit on the other hand. Numerous studies suggest adopting a conservative approach in normal conditions because interests of conservative approach outweigh its costs. There is the possibility of familiarity (or even friendship) between the audit team members and client's staff in auditory institutions with long-term audit tenure; it increases the probability of destruction of auditing program. Then, it reduces the likelihood of making decisions contrary to past years; hence, they may present and less efficient and lower quality auditing. In this manner, increasing auditor tenure will be accompanied by reduction in accounting conservatism. This conclusion is in line with the findings in [9]. The results of testing second hypothesis (client importance has additive effect on the inverse relationship between auditor tenure and conservatism of clients) is consistent with the findings in [9]. In this regard, it should be explained that auditors show more leniencies to the clients who are more important in terms of remuneration and credit. Accordingly, they try more to maintain the client. In this way, increasing client importance adds the effect of auditor tenure on conservatism.

\section{REFERENCES}

[1] S. Basu, "The conservatism principle and the asymmetric timeliness of earnings", Journal of Accounting and Economics, Vol. 24, No. 1, pp. 337,1997 
[2] R. L. Watts, "Conservatism in accounting part I: Explanations and implications", Accounting Horizons, Vol. 17, No. 3, pp. 207-221, 2003

[3] R. Watts, J. Zimmerman, Positive Accounting Theory. Prentice-Hall, Englewood Cliffs, NJ, 1986

[4] P. A. Copley, "The association between municipal disclosure practices and audit quality", Journal of Accounting and Public Policy, Vol. 10, No. 4, pp. 245-266, 1992

[5] G. Colbert, D. Murray, "The Association between Audit Quality and Auditor Size: An Analysis of Small CPA Firms", Journal of Accounting, Auditing and Finance, Vol. 13, No. 2, pp. 135-150, 1998

[6] M. Dao, T. Pham, "Audit tenure, auditor specialization and audit report lag", Managerial Auditing Journal, Vol. 29, No. 6, pp. 490-512, 2014

[7] H. Y. Lee, V. Mande, M. Son, "Do lengthy auditor tenure and the provision of non-audit services by the external auditor reduce audit report lags?", International Journal of Auditing, Vol. 13, No. 2, pp. 87104,2009

[8] U. S. Congress, The Sarbanes-Oxley Act of 2002, 107th Congress of the United States of America, H. R. 3763, Washington, D.C., Government Printing Office, 2009

[9] L. K. Rickett, A. Maggina, P. Alam, “Auditor Tenure and Accounting Conservatism: Evidence from Greece", Managerial Auditing Journal, Vol. 31, No. 6, pp. 10-25, 2016

[10] R. A. Price, Accounting Conservatism and The Asymmetry in The Earnings Response to Current and Lagged Returns, Stanford University, 2005.

[11] V. E. Johnson, I. K. Khurana, J. K. Reynolds, "Audit-firm tenure and the quality of financial reports", Contemporary Accounting Research, Vol. 19, No. 4, pp. 637-660, 2002

[12] D. Citron, R. Taffler, "The audit report under going concern uncertainties: An empirical analysis", Accounting and Business Research, Vol. 22, No. 88, pp. 337-346, 1992

[13] M. A. Geiger, K. Raghunandan, "Auditor tenure and audit reporting failures", Auditing, Vol. 21, No. 1, pp. 67-78, 2002

[14] J. N. Myers, L. A. Myers, T. C. Omer, "Exploring the term of the auditor-client relationship and the quality of earnings: A case for mandatory auditor rotation?", The Accounting Review, Vol. 78, No. 3, pp. 779-799, 2003

[15] J. V. Carcello, A. L. Nagy, "Audit Firm Tenure and Fraudulent Financial Reporting", Auditing: A Journal of Practice \& Theory, Vol. 23, No. 2, pp. $55-70,2004$
[16] M. L. Defond, K. R. Subramanyam, "Auditor changes and discretionary accruals", Journal of Accounting \& Economics, Vol. 25, No. 1, pp. 3568, 1998

[17] B. Arel, R. G. Brody, K. Pany, "Audit Firm Rotation and Audit Quality”, The CPA Journal, Vol. 75, No. 1, pp. 36-39, 2005

[18] S. K. Gates, D. J. Lowe, P. M. J. Reckers, "Restoring public confidence in capital markets through auditor rotation", Managerial Auditing Journal, Vol. 22, No. 1, pp. 5-17, 2007

[19] M. Dao, S. Mishra, K. Raghunandan, "Auditor tenure and shareholder ratification of the auditor", Accounting Horizons, Vol. 22, No. 3, pp. 297-314, 2008

[20] B. W. Daniels, Q. Booker, "Loan Officers' Reactions to Audit Rotation", Journal of Behavioral Studies in Business, Vol. 1, No. 1, pp. 1-13, 2009

[21] A. Nagy, "Mandatory Audit Firm turnover, financial reporting quality and client bargaining power: the case of Arthur Andersen", Accounting Horizons, Vol. 19, No. 2, pp. 51-68, 2005

[22] A. B. Jackson, M. Moldrich, P. Roebuck, "Mandatory Audit Firm Rotation and Audit Quality", Managerial Auditing Journal, Vol. 23, No. 5, pp. $420-437,2008$

[23] D. Mostafa, The Impact of the Auditor Rotation on the Audit Quality: A Field Study from Egypt, SSRN, 2010

[24] M. Cameran, P. Annalisa, M. Trombetta, Mandatory Audit Firm Rotation and Audit Quality, European Accounting Review Forthcoming, SSRN, 2014

[25] M. Bani Mahd, M. Morade Zade Fard, M. Zeinali, "The relationship between changing independent auditor and the auditor's report", Journal of Accounting Knowledge, Vol. 4, No. 14, pp. 91-108, 2013

[26] E. Malekian, F. Abdi poor, "The relationship between changes of audit firm and conservative reporting profits of companies listed on the Tehran Stock Exchange", Journal of Accounting Knowledge, Vol. 11, No. 41, pp. 173-157, 2014

[27] H. Vakili Fard, S. Muhammadi, "Audit Firm Rotation and Type of Audit Report”, Research of Financial Accounting and Auditing, Vol. 7, No. 25, pp. 33-48, 2015 